\title{
AN OVERVIEW OF OLD TIBETAN SYNCHRONIC PHONOLOGY
}

\author{
By Nathan W. Hill \\ School of Oriental and African Studies, University of London
}

\begin{abstract}
Despite the importance of Old Tibetan in the Tibeto-Burman language family, little research has treated Old Tibetan synchronic phonology. This article gives a complete overview of the Old Tibetan phonemic system by associating sound values with the letters of the Tibetan alphabet and exploring the distribution of these sounds in syllable structure.
\end{abstract}

\section{INTRODUCTION}

Since Tibetan is among the oldest and most widely studied of the Tibeto-Burman languages, one would perhaps expect Old Tibetan phonology to be well researched. This is not the case. The available grammars of Written Tibetan describe how to pronounce Written Tibetan in the reading style of Lhasa or other central Tibetan dialects, but otherwise give no attention to pronunciation, let alone phonology (Hahn 1994: 3-28; Hodge 1990: 5-10). ${ }^{1}$ There is no reference grammar of Old Tibetan, and only a handful of papers devoted to Old Tibetan phonology. ${ }^{2}$ The only previous attempt to formulate an overall survey of Old Tibetan segmental phonology is Jäschke (1868). Although much basic research remains undone, an attempt to make available a synchronic overview of Old Tibetan phonology will conveniently present those facts which are well established and sharpen the picture of what remains to be done.

\subsection{Background}

The Stammbaum of Tibeto-Burman, in particular the place of Chinese within it or as a sister branch in a larger the Sino-Tibetan family, is highly controversial (van Driem 2003). There is, however, general agreement that Tibetan is on the Bodish branch of Tibeto-Burman. Robert Shafer, who introduced this terminology, imagined the Bodish family as consisting of four inner branches (West Bodish, Central Bodish, Southern Bodish, and East Bodish) and three outer branches (Tsangla, Gurung, and Rgyalron) (1966: 78-123; see Figure 1). Shafer considers both Central Bodish and Southern Bodish to be descendants of Old Tibetan (p. 87). It is unclear whether he believes Central Bodish and Southern Bodish are genuine subgroups in their own right, or whether they are convenient geographical labels for discussing the daughter languages of Old Tibetan.

\footnotetext{
${ }^{1}$ This generalisation is not true of Beyer (1992: 55-66), who does attempt to describe the phonology of Written Tibetan. However, he takes the letters of the script as being in a one-to-one relationship with the phonemes.

${ }^{2}$ Laufer (1914), Dragunov (1936; 1939), Che (1981; 1984), Beckwith (2006), Hill (2005; 2006; 2007; 2009b; forthcoming). 


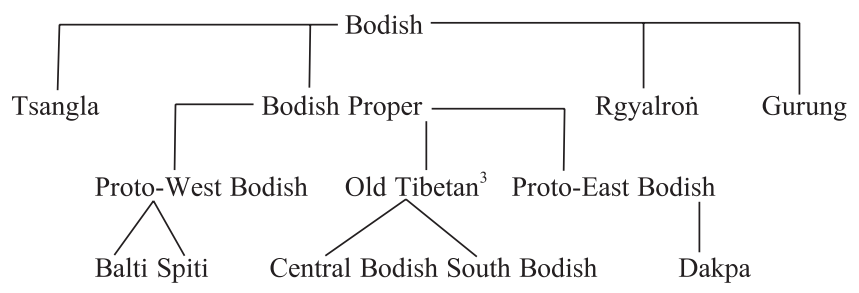

Figure 1. The Bodish family (after Shafer 1966: 113)

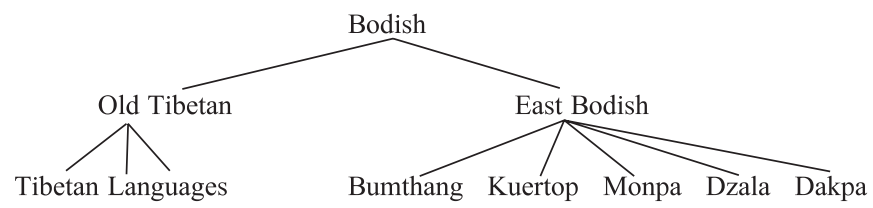

Figure 2. Revised Stammbaum of Bodish family

Although van Driem acknowledges some of the mistakes in this Stammbaum, he accepts it grosso modo (van Driem 2001: 826-908). There are two major objections to be made to Shafer's scheme; Rgyalron is now widely recognised to be a sub-branch of the Qiangic family (Jacques 2004: 3), and, despite the enthusiasm of Bielmeier for the West Bodish hypothesis (2004), because Baltistan and Ladakh were Dardic-speaking before the invasion of the Tibetan empire (Petech 1977: 5-13), Balti and Ladakhi are direct daughter languages of Old Tibetan, just like the other Tibetan languages. Because the relationship of Tsangla and Gurung to Tibetan is not well investigated, I believe that Figure 2 represents a more judicious Stammbaum. Since neither the Bodish branch itself nor its sub-branches have been demonstrated through shared innovation, this Stammbaum serves merely as a working hypothesis.

Old Tibetan was originally the language spoken in the Yarlung valley, the cradle of the Tibetan empire. During the empire's initial expansion, writing was introduced in 650 CE to facilitate administration. ${ }^{4}$ Together with the troops of this empire, the Old Tibetan language colonised the entire Tibetan plateau, extinguishing almost all of the languages formerly spoken across that territory. Most famously, Źanźun, the language of an older polity in western Tibet and the sacred tongue of the Bon faith, succumbed to the pressure of an expanding Tibetan Sprachgebiet.

The use of Old Tibetan across and beyond the plateau at the height of the empire in the ninth century set the stage for the breakup into the spoken languages of today, which together constitute the Tibetan language family. The Stammbaum of the Tibetan family is no better understood that that of the Bodish family. There is a typological tendency for the languages of central Tibet to have phonemic tone as well as relatively simplified syllable structure, whereas the dialects of the periphery lack tone and have complex syllable structure. Individual Tibetan languages are usually classified into groups based on the provinces of Tibet they are

\footnotetext{
${ }^{3}$ Shafer refers to Old Tibetan as 'Old Bodish'.

${ }^{4}$ In $648 \mathrm{CE}$ the Chinese were asked to send paper and ink to Tibet (Laufer 1918; Pelliot 1961: 6; Lee 1981: 13). Two years later, in 650 CE, dated entries in the Old Tibetan Annals (PT 1286) begin (cf. Dotson 2009: 83), indicating that systematic government record keeping began in this year. In citing Old Tibetan manuscripts, the abbreviation PT followed by a number refers to the manuscript number in the 'Pelliot tibétain' collection of the Bibliothèque Nationale; the abbreviation ITJ followed by a number refers to the manuscript number of the India Office Library Tib $\mathrm{J}$ collection of the British Library.
} 
spoken in; one reads therefore of 'Khams dialects', 'Amdo dialects', etc. (Denwood 1999: 2336; Tournadre \& Dorje 2003: 28-32). The identity of such geographical groupings with genetic groupings has never been demonstrated through the tracing of shared innovations, and is best regarded as a heuristic. ${ }^{5}$ Because Tibetan languages began to diverge from each other some centuries after Old Tibetan was committed to writing, the written system represents an état de langue (Old Tibetan) older than that reconstructible via the comparative method (Common Tibetan).

Old Tibetan continued to be used as a lingua franca of commerce and administration in the oasis cities of the Silk Road for some decades after the Tibetan empire lost control of these territories (Uray 1981; 1988; Takeuchi 1990: 187-9). Thus, non-native speakers of Old Tibetan composed some of the extant Old Tibetan documents found at Dunhuang and in the deserts of Central Asia.

With the collapse of the empire and the increasing mutual unintelligibility of the dialects, Old Tibetan ceased to exist. However, a relatively stable but changing written standard, referred to as 'Written Tibetan' in linguistic literature or 'Classical Tibetan' by Tibetologists, continued to be used throughout the Tibetan cultural area from the collapse of the empire until the present day. For reasons that are hard to understand, the bulk of work on TibetoBurman historical linguistics (e.g. Benedict 1972; Matisoff 2003) employs Written Tibetan as presented by Jäschke (1881), rather than making use of Old Tibetan.

In some cases owing to political domination and in others because of the influence of Tibetan Buddhism, various forms of Tibetan have had considerable influence on neighbouring languages. Rgyalronic languages (Jacques 2004: 83-199), Burushaski (Lorimer 1938: 532 6), and the Monguor variety of Mongolian (Róna-Tas 1966) have extensively borrowed from Tibetan languages. These contact situations, dating from various periods, have not been subject to much investigation. Contact with the Rgyalronic languages, on account of the very conservative phonology of their Tibetan loanwords, appear to have begun quite early (Jacques 2004: 178-200).

Contact influences on Old Tibetan have received even less attention than the impact of Tibetan varieties on the languages of other families in the region. Speakers of Dardic languages occupied the greater part of Baltistan and Ladakh prior to colonisation by Tibetan-speaking populations in about 900 (Petech 1977: 5-13); a substrate influence from Dardic languages on the Tibetan languages of these regions is certainly worthy of consideration. I put forward a conjecture in this article that the Qiangic languages of the East had an influence on the development of uvulars in the phonologies of the Tibetan languages in their region.

\subsection{Scope of the present study}

A variety of sources are available for the study of Old Tibetan phonology, each pointing to a somewhat different language. The spellings of Old Tibetan record how speakers of Old Tibetan chose to record the pronunciation of their language, in particular at the time of the invention of the writing system in $650 \mathrm{CE}$. The study of Old Tibetan loanwords in other languages, when combined with an understanding of the historical phonology of the receiving language, gives a picture of the phonology of the donor Tibetan dialect at the time of the loan. Comparative study of the dialects gives a picture of Common Tibetan at the moment before it broke into its multitude of contemporary dialects. Finally, transcriptions of Tibetan words into other scripts show their pronunciations as they sounded to a foreign ear at the time of the transcription.

\footnotetext{
${ }^{5}$ J. Sun argues strongly against the value of this heuristic (2003: 794-7).
} 
A fully fledged study of Tibetan historical phonology would take all of these forms of data fully into account. ${ }^{6}$ Here, Old Tibetan phonology is described primarily on the basis of the orthography of Old Tibetan texts. One might object that, because in many well-known cases the orthography of a language and its phonology diverge widely (English, French, etc.), this reliance on orthography is unjustified. Such situations are typical of languages that use the same or similar writing systems to their neighbours and have a long tradition of writing. When a language without a previous written tradition adopts a script of its own in one go, such as Cherokee or Lepcha, this problem does not occur. A straightforward relationship between writing and pronunciation serves as the starting point for work on the phonology of Greek, Latin, Sanskrit, Classical Japanese, and even Old Chinese, and there is no reason to approach Old Tibetan otherwise.

In this study the phonetic value of the letters will be gathered from their corresponding uses in Indic scripts, by the linguistic analysis implied by Tibetan alphabetical order, and with occasional reference to the phonetically conservative Tibetan dialects of Themchen in the far East (Haller 2004) and Balti in the far West (Sprigg 2002). If a phonemic distinction is not captured by the script, it will not be recovered in this study. Taking the letters as basic units, once a sound is associated with each letter, the distribution of these sounds is examined to determine the phonological system.

\section{From LetTers to SOUNDS}

The Tibetan script contains the letters shown in Figure 3, in the traditional order for Written Tibetan. Each letter is given in Tibetan script, in transcription, ${ }^{7}$ and then followed by a hypothetical phonetic value, for those cases where the transcription employs characters outside the IPA.

\subsection{Consonants}

Which Indic script served as the model for the Tibetan script remains uncertain; a script of Kashmir in the middle of the seventh century is currently the best candidate (Uray 1955: 106). The fact that Indic scripts are organised along phonetic principals greatly aids the phonetic interpretation of the Tibetan script.

\subsubsection{The first sixteen letters}

The first sixteen letters are organised in a manner exactly parallel to those of the Indic scripts. The rows represent places of articulation (velars, palatals, dentals, and labials) and the columns represent manner of articulation (voiceless unaspirated, voiceless aspirated, voiced, and nasal). The Indic column for voiced aspirates, or, in the terminology of contemporary phonologists, 'murmured' consonants, is missing because these sounds are absent.

\footnotetext{
${ }^{6}$ Studies of loanwords from Tibetan into other languages include Róna-Tas (1962; 1966) for Monguor, Emmerick (1983; 1985) for Khotanese, de Roerich (1957) for Mongolian, and Jacques (2004) for Japhug Rgyalron. Studies of loanwords into Tibetan include Laufer (1916/18; 1919) from various languages, Emmerick (1983; 1985) from Khotanese, and Beckwith \& Walter (1997) from Indo-European. Studies of Tibetan words written in other scripts include Laufer (1914), Miller (1955b), Zhang (1987), Che (1991) and Róna-Tas (1992). Studies concerning the influence of Tibetan on Tokharian include Sapir (1936) and Ivanov (1961). A newly discovered source for Tibetan historical phonology is a collection of Dunhuang texts which are the transcripts of oral teachings, and give information about the pronunciation of Tibetan in medieval Dunhuang (van Schaik 2007).

${ }^{7}$ The transcription system used is Library of Congress with the substitution of $\langle\mathrm{h}\rangle$ for $\langle$ ' $\rangle$. When sounds rather than letters are under discussion the appropriate International Phonetic Alphabet (IPA) symbol will be used. Phonemes are enclosed in slashes / / and sounds in brackets [].
} 


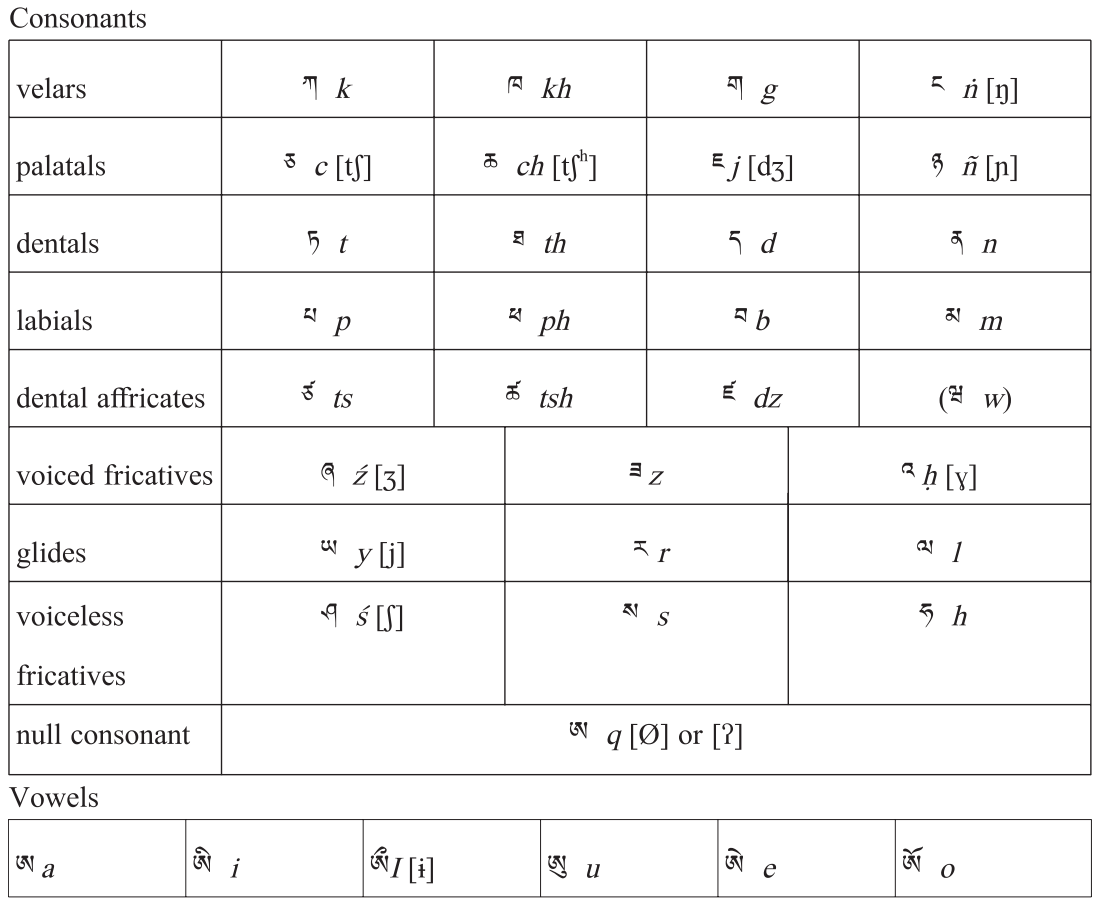

Figure 3. The Tibetan script

\subsubsection{The affricates $\mathrm{ts}, \mathrm{tsh}$, and $\mathrm{dz}$}

The next three letters, ${ }^{\circ} t s$, $\bar{\delta}^{\circ} t s h,{ }^{5} d z$, are quite clearly derived via a diacritic from the palatal series ${ }^{\Xi_{C}}, \Phi_{c} h, \boldsymbol{E}_{j}$. They must then represent sounds similar to palatals which do not occur in Sanskrit. Dental affricates would be a good candidate, and this supposition is confirmed by the dialects. Themchen dialect has rtse-mo /stsemu/ 'Spitze (peak)' (Haller 2004: 331), tshe $/ \mathrm{ts}$ e/ 'Lebensdauer [lifetime]' (p. 346), and $m d z o / m d z o /$ 'Dzo (männliche Kreuzung von Yak und Hausrind [a male cross of a Yak and cow])' (p. 270). Balti has bu-rtse /bu-rtse/ [burtse] 'mountain-side aetimaesia' (Sprigg 2002: 34) and tshe /tshe/ [ts $\left.{ }^{\mathrm{h}} \mathrm{e}\right]$ 'life' (p. 170).

\subsubsection{The letter $\mathrm{w}$}

Uray (1955) has shown that the next Written Tibetan letter ${ }^{2} w$ is originally a digraph $h w$ - and did not exist as an independent letter in Old Tibetan. The one word frequently written with win Written Tibetan is wa 'fox'. Reflexes of this word in the Tibetan languages point clearly to *[ywa], which exactly fits an Old Tibetan spelling hwa (Hill 2006: 80-83). Although Old Tibetan lacks initial w-, it does have a character for medial $-w$-, i.e. $<>$. This letter is found in the spellings of the following words: grwa 'corner' (PT 1134 line 190), phywa 'a class of gods' (PT 0126 line 14 et passim), rtswa 'grass' (PT 1136 line 36 et passim), hwa 'fox' (PT 1134 lines 93, 94, 98), rwa 'horn' (ITJ 0730 line 33). It is commonly believed that the character $\langle>$ in such words is nothing more than a diacritic and did not represent a sound (Benedict 1972: 49; Beyer 1992: 79-81). I have argued elsewhere that it represented the sound [w] (Hill 2006: 83-8).

\subsubsection{The liquids and fricatives}

The liquids and the voiceless fricatives, $y, r, l, s, s, h$ also parallel exactly their Indic equivalents. The voiced fricatives $\dot{z}, z, h$ by their position in the Tibetan alphabet correspond 
to their respective voiceless counterparts. The phonetic value of the letters $\langle\dot{z}\rangle$ and $\langle\mathrm{z}\rangle$ can also be validated by reference to the contemporary Tibetan languages. Themchen has such forms as bźi /bzə/ 'vier [four]' (Haller 2004: 221) and gzims /yzəm/ 'sich hinlegen (hfl.) [lay down (polite)]' (p. 243). Balti has /bźi/ [bji] 'four' (Sprigg 2002: 38) and /gzim/ [rzim] 'sleep (hon.)' (p. 73). The phonetic value of $\langle h\rangle$ as a voiced velar fricative in all phonotactic positions has been one of the major focuses of my previous research (Hill 2005; 2009a; 2009b). The letter $<\mathrm{h}>$ quite clearly derives from the Indic letter which is similarly transliterated. However, whereas in Sanskrit the letter $<\mathrm{h}->$ represents a voiced sound, the placement of Tibetan letter $<\mathrm{h}>$ in alphabetical order after $\langle\mathrm{s}\rangle$ and $<\mathrm{s}\rangle$, and the phonotactic distribution of $/ \mathrm{h}-/$ in the Old Tibetan syllable, clearly indicate that in Tibetan $<\mathrm{h}>$ represents a voiceless sound. Words that begin with $h$ are few in number; apart from transcriptions of names and foreign words, I find only ha-chain, a term used in divination (PT 1047 line 1, PT 1283 line 81 et passim) and ha-tsu-tsu, an interjection of distress (PT 1285 recto, lines 110,150 , and 165$)$.

\subsubsection{The letter $<\mathrm{q}>^{8}$}

The final letter of the Tibetan alphabet, $q$, has been the subject of some controversy. The Indic ancestor of the letter $q$ is used to represent vocalic onset, and the corresponding letter in the Hphags-pa script $\mathbb{V}^{\mathrm{V}}$ also represents vocalic onset (Ligeti 1961: 204-12). However, it has been suggested that in Tibetan $q$ - indicates a glottal stop [?]. Jäschke describes it as such (1881: xiv), presumably for the reading pronunciation of Ladakh, as does Miller for 'Central' Tibetan (1955a: 47 \$1.3.2 and 49 §3.3.1). However, in some dialects, words spelled with initial $q$ - are pronounced as beginning with simple vowels (e.g. Balti, cf. Bielmeier 1985: 245; Gźis-ka-rtse, cf. Haller 2000: 296; Diniri, cf. Herrmann 1989: 304-5). In other dialects, there is no contrast between initial glottal stop and initial vowel (e.g. Drokpa, cf. Kretschmar 1986: 21).

Zhang (1987: 41-6) gives three reasons why she thinks $q$ - represents a glottal stop in Old Tibetan. First, the transliteration of the Chinese character - 'one' in one text as qyi and not $y i$ reflects a glottal stop in Chinese. Second, the Tibetan grammarians describe the letter as a consonant and not as a vowel. Third, Zhang's paraphrase of the Chinese translation of the Gser tog sum rtags reads: 'when producing the sound $q$ the middle part of the tongue should be lifted near the palate' (1987: 46). She does not quote the Tibetan text (or the Chinese translation which appears in her bibliography), nor does she cite a page number. She seems to have intended the passage 'ya ni rkan-las byun-źing lcehi rked-par cun-zad ñe-bahi byed-pas bskyed-cin / brjod tshul ni sin-tu lhod-pa-dan / The y, arising from the palate, is produced by nearing the middle of the tongue a little [to the palate]; the mode of articulation is very relaxed' (Blo bzan tshul khrims rgya mtsho 1962[1891] : 48, my translation). Zhang, or the Chinese translator she follows, appears to have been misled by the graphic similarity of the letter $w \mathrm{y}$ and $\mathrm{q}$ in the Tibetan script.

As for her first reason, Zhang herself admits that another motivation for such a transliteration is to match the tone of the Chinese original more closely (1987: 42). Regarding her second reason, it should be remarked that $q$ - does not function in the Tibetan script as a vowel, but rather as a null consonant. The vowel $a$ is inherent in any akșara unless another vowel is added to it. The interpretation of the letter $q$ - as marking vocalic onset is thus fully consistent with the indigenous description of it as a (null) consonant. Finally, her quotation from Blo bzan் tshul khrims rgya mtsho is based on an error; the correct citation reads as follows.

\footnotetext{
${ }^{8}$ This section supersedes the similar discussion in Hill (2005: 108-9), which contains some errors.
} 
dbyañs-gsal gñis chod qa yig ni mgrin-pa-nas byuñ-źin lce-rtsa-dan் mgrin-pa sbyar-bahi byed-pas bsyed-cin / brjod-tshul ni ches-źin-tu lhod-źan-pas źan-pahi sgra-gdañ-las rtags med-paho

[The letter $q$, which is apart from both vowels and consonants, arises from the throat; it is produced by making the throat and the tongue root join. As for the mode of articulation, because it is extremely weak and relaxed, there is no distinguishing characteristic other than the mere weak sound of speech.] (Blo bzan tshul khrims rgya mtsho 1962[1891]: 48, my translation)

This description exactly matches the proposal made here, that $q$ - represents a zero initial.

Even if Blo bzan் tshul khrims rgya mtsho, writing in 1891, had described $q$ - explicitly as a glottal stop, this would seem little relevant to the pronunciation during the Old Tibetan period a thousand years earlier. There are thus no strong arguments for analyzing $q$ - as a glottal stop onset as opposed to vocalic onset. Since the Indic ancestor of this letter indicates an initial vowel, as does its heir in the Hphags-pa script, the neutral position is to assume that $q$ - similarly indicated an initial vowel in Old Tibetan. Perhaps all vowel-initial words were articulated with a sub-phonemic glottal stop as in German; in this case $q$ - may have been accompanied by a glottal stop, but it certainly does not itself represent a glottal stop. This letter is exceedingly rare in Old Tibetan, and it is unclear whether any genuine Tibetan words began with a vowel (glottal stop). Perhaps, therefore, determining its phonetic value is moot.

\subsection{Vowels}

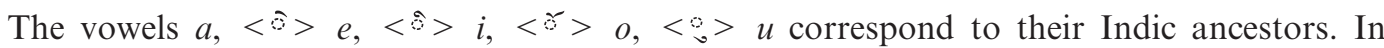
addition, Old Tibetan employs a backwards $\mathrm{i}\langle\dot{<}\rangle$ frequently called gigu inversé in the literature and transcribed here as $\langle\mathrm{I}\rangle$. The corresponding Indic letter indicates a long $\mathrm{i}$ vowel. Tibetan has no distinction of vowel length, so this letter's function in Tibetan must be sought elsewhere. Whether or not the character $<\mathrm{I}>$ represents a phonetic reality remains controversial. Laufer (1914: 84) and Miller (1966; 1993: 156-72) argue that the two represent sub-phonemic allophones [i] and [i]. The distributions they claim for these allophones have not been rigorously demonstrated and have many exceptions. Other authors (e.g. Ulving 1972; Róna-Tas 1992: 698-9) have regarded these two characters as meaningless graphic variants. Even if this contrast between the two graphs is meaningful, the contrast between [i] and [i] would remain subphonemic. Miller (1967) also argues that in one Old Tibetan document an altered $u$ graph is used to represent a front unrounded vowel in transcribing Chinese. Unfortunately no further research has followed up on this suggestion.

There are generally no diphthongs in Old Tibetan; the one exception is the syllable /oe/ which occurs as an alternate for /ohi/, i.e. the genitive suffix when following an /o/ (cf. Che 1984; Richardson 1985: 18). An example of this phenomenon is the phrase phagI loe dphyId 'spring of the year of the pig' (PT 1088 line 1), which shows both the normal genitive suffix -i after the word phag 'pig' and the form -e after the word lo 'year'; compare the phrase khyihi lohi dpyid 'spring of the year of the dog' (PT 1089 recto, line 43).

Laufer suggests that Old Tibetan must have had the vowel $\varnothing$ in addition to the vowels marked in the script.

tib. $e[\ldots]$ hat ausser dem Werth e in den früheren Zeiten auch den von ö gehabt, worauf meines wissens freilich bisher noch niemand hingewiesen: es ist aber völlig klar, dass, wenn $r d e(u)$,Steinchen' aus rdo-bu, med, nicht sein' aus ma-yod, k'yed,du' [sic Ihr] aus $k^{\prime}$ yod ['du'] enstanden ist, in diesen Fällen eine Zwischenstufe rdö, möd, k'yöd angenommen werden muss. 
[Tibetan $e .$. had in earlier times in addition to the value $e$ also that of $\ddot{o}$, which to my knowledge no one has hitherto remarked upon: it is however fully clear that if rdehu 'small stone' comes from rdo-bu, med 'not exist' from ma yod, and khyed 'thou' [sic you] from khyod, in these cases an intermediate phase $r d \ddot{o}$, möd, khyöd must be reckoned with.] (1976[1898/9]: 117, my translation)

While perhaps Laufer is correct to internally reconstruct this vowel, even if it was articulated as a sound in the Old Tibetan period it was not a phonemic distinction.

\section{FROM SOUNDS TO PHONEMES}

Now that the sounds corresponding to the various Tibetan letters have been determined, an examination can be made of how these sounds are distributed in the phonological system of Old Tibetan.

\subsection{The non-phonemic status of aspiration}

The aspirated and unaspirated voiceless consonants are in complementary distribution. According to the proscriptive rules of Written Tibetan, consonants are aspirated in clusters with initial /h-/, and /m-/ (e.g. hchad 'be cut', mchis 'stay, go'), while consonants are unaspirated in clusters with /d-/,/g-/, /b-/, /s- / and /r-/ (e.g. dkah 'difficult', gcod 'cut', bcug 'insert, appoint', skyibs-lug 'psychopomp sheep', rkyan் 'equus hemionus'). These rules are not observed in Old Tibetan, where the same word may be written indiscriminately with an aspirated or unaspirated cluster, even within a single document (mcis PT 1096 recto, line 2 et passim, mchis line 10 et passim; gcod PT 1287 line 35 et passim, gchod line 181 et passim; bcug ITJ 0750 line 160 et passim, bchug line 194 et passim; skyibs-lug PT 1134 line 127 et passim, skhyibs-lug line 193; rkyan் ITJ 0731 recto, line 51 et passim, rkhyan recto, lines 85, 87, 91). In Written Tibetan, aspirated and unaspirated voiceless consonants are in opposition in syllable-initial position ( $k a$ 'pillar', $k h a$ 'mouth'). The result of a study of aspirated and unaspirated voiceless consonants in Old Tibetan inscriptions demonstrates that, in contrast to Written Tibetan, aspiration in Old Tibetan is subphonemic, the simplex syllable initial of a word being aspirated and a simplex syllable initial within a word unaspirated (Hill 2007: 479-89, e.g. khol-yul 'fief-land' Źol inscription, north face, line 29, Li \& Coblin 1987: 149, versus gnam-kol 'servant of heaven' Rkon-po inscription, line 8, Li \& Coblin 1987: 198). Two genuine Old Tibetan words appear to be exceptions to this pattern, but can be explained without introducing a phonemic contrast of aspiration. One, kun 'all', is spelled unaspirated because of a morphophonemic tendency of the orthography, and the other, $c i$ 'which, what', is treated phonetically as belonging to the preceding word (Hill 2007: 481-2). A few loanwords from Chinese, e.g. con (Bsam-yas bell inscription line 4, Li \& Coblin 1987: 334) <鐘 zhōng 'bell', kuńco (Źol inscription, South side, lines 67-8, Li \& Coblin 1987: 145; Sino-Tibetan treaty inscription of 821-2, East side, lines 24 and 28, Li \& Coblin 1987: 48) <公主 gōngzhü 'queen', do break the pattern. Some may feel that it is necessary to introduce a phonemic contrast of aspiration in order to account for these loanwords. For the purpose of historical linguistics, it seems more judicious here to disregard these loans.

\subsection{The distinction between $/ y /$ and $/ i /$}

The Tibetan script distinguishes two ways in which the letter ${ }^{4}\langle\mathrm{y}\rangle$ can follow the letter $\nabla$ $\langle\mathrm{g}\rangle$. In one case $\langle\mathrm{y}\rangle$ appears to the right of $\langle\mathrm{g}\rangle$ horizontally बाw; this is usually 
transliterated $\langle$ g.y $\rangle$. In the other case the $\langle\mathrm{y}\rangle$ appears below the $\langle\mathrm{g}\rangle$, i.e. D; this is transliterated as $\langle$ gy $\rangle$. A minimal pair can be found with the word g.yain 'sheep' (PT 1047 line 222) and gyain 'also, and' (PT 1047 line 59). Following Walleser (1926: 9), I have argued that the difference between $<\mathrm{g}$.y $>$ and $<$ gy $>$ is the difference between $/ \mathrm{gy} /[\mathrm{gj}]$ and $\left./ \mathrm{gi} / \mathrm{g}^{\mathrm{j}}\right]$ (Hill forthcoming). Because this difference is indicated simply by the graphic position of these letters, it is necessary to extend the phonetic differentiation of $\langle y\rangle$ into $/ y /$ and $/ \mathrm{i} /$ of this one case to the interpretation of $\langle y\rangle$ in these two graphical positions in general. It is important to distinguish $/ \mathrm{y} /$ (a palatal glide) and $/ \mathrm{i} /$ (a phonemic feature of palatalisation) throughout Old Tibetan phonology.

\subsection{The phonemic status of the palatals}

Noticing that the letter $\langle\mathrm{y}\rangle$ when indicating the feature of palatalisation $/ \mathrm{i} / \mathrm{cannot}$ follow a dental or a palatal $\left(* d y,{ }^{*} c y\right)$, but can follow velars and labials $(k y, b y)$, it is tempting to analyse the palatals as a palatalised dental, i.e. $/ \mathrm{ti} /$ for $\langle\mathrm{c}>, / \mathrm{ni} /$ for $<\tilde{\mathrm{n}}>$, $/ \mathrm{di} /$ for $<\mathrm{j}>$, /si/ for $<\mathrm{s}>$, and /zi/ for $<\mathrm{z}>$. A further ground for accepting this analysis is that the dentals can be followed by the glide $/ \mathrm{r} /(d r, s r)$ but the palatals cannot $(* c r, * j r, * s r)$, just as velars or labials can be followed by the glide $/ \mathrm{r} /(k r, b r)$ but the palatalised velars and palatalised labials cannot $\left({ }^{*} k y r,{ }^{*} b y r\right)$. The palatals $(c, j, \tilde{n})$ only occur immediately before a vowel, never as final consonants, and never as the initials of clusters. If the palatals are regarded as unitary consonants, there is no way to explain this distribution. However, if they are regarded as palatalised dentals, this distribution exactly parallels the velars and labials, which can occur in any syllable position unpalatalised but only before a vowel when palatalised. The fact that Indic alphabets have a palatal series may have inclined the originators of the Tibetan script in choosing not to spell these sounds as single consonants.

\subsection{The digraphs $<h r>$ and $<l h>$}

The two letter combinations $<$ lha $>$ and $<$ hra $>$ do not represent clusters as they appear to, but rather the voiceless equivalents of $/ 1 /$ and $/ \mathrm{r} /$, i.e. $/ 1 /$ and $/ \mathrm{r} /$ (cf. Sprigg 1967: 217; Hahn 1973: 434). In Themchen, the reflex of $<1 \mathrm{~h}>$ is $/ 1 /$, e.g. Iha $/ \mathrm{la} /$ 'Gottheit' (Haller 2004: 264). Balti gives this word as $/$ ha/ [la] 'idol, Buddhist deity, fairy' (Sprigg 2002: 101). Źo-nu has $<$ lha $>$ /le / 'god, Buddha' (J. Sun 2003: 772).

J. Sun, however, notes that in Źo-nu 'The voiceless lateral $/ 1 /$ may be alternatively realised as a consonant cluster [вl] $\sim[\chi 1] \sim$ [11]' (2003: 772). He wonders whether the Old Tibetan pronunciation of $<\mathrm{lh}>$ may have in fact been as a cluster:

Supporting evidence of the cluster origin of O[ld ]T[ibetan] *hl- comes from its Dégé (德格 $<$ sDe.dge $>$; [ ${ }^{\mathrm{h}}$ l]) and Záduō (雜多 < rDza.rdo > ; [hl]) reflexes (Zhang 1996:23); in Baima likewise, words like lha $<$ hla $>$ [sic $<$ lha $>$ ] 'god' carry the suggestive breathy register indicating a proto-sonorant cluster. Another remnant of $* h l$ - as an earlier consonant cluster is the pronunciation $\chi a m$ (written $<1$ ham $>$ 'boot') current in certain dialects spoken in the Amdo region. (J. Sun 2003: 787-8)

I do not find this evidence conclusive. Sun does not say why he believes $<\mathrm{lh}>$ should be reconstructed as $* h l$, the reverse of what the script indicates. The initial $\chi$ - of the word $<$ lham $>\chi$ am 'boot' is not a cluster. It is unclear why Sun sees it as evidence for a protocluster. The relationship of Baima to the other Tibetan languages remains controversial (Zhang 1997; H. Sun 2003); several layers of correspondences exist between Baima and Written Tibetan, and until these are worked out it is premature to make much of the Baima 
form. Beyer (1992: 46 n. 9) has also suggested that the spelling $<$ lh $>$ reflects a genuine cluster pronunciation in Old Tibetan. He cites as evidence doublets such as lhan, glan 'patch' and lhog, glog 'ulcer', as well as the fact that Old Tibetan $<\mathrm{lh}\rangle,\langle\mathrm{sl}\rangle$, and $\langle\mathrm{gl}\rangle$ have all merged as $l h$ in an unspecified dialect of Ladakh. I fail to see the relevance of any of these facts.

If these digraphs were to have represented a cluster with $h$, they would be the only two such clusters in Tibetan phonology. In the case of $<\mathrm{lh}>$, the $<\mathrm{h}>$ appears to represent aspiration. Aspiration is not a phonemic contrast in general in Old Tibetan phonology. It would be untidy to introduce it as a contrast for these examples only. Since in Old Tibetan all members of the cluster have the same voicing, if this $<\mathrm{h}>$ did represent aspiration, either the $l$ in this case would be unvoiced, or the $h$ would be voiced. If the $h$ were voiced, then $<1 \mathrm{~h}>$ would appear to represent a murmured or voiced aspirated consonant. Such consonants do not otherwise occur in any variety of Tibetan. This leads to the conclusion that even if $l h$ were taken to represent an aspirated lateral, this would imply a voiceless lateral. Since voicing, unlike aspiration, is a major contrast in Tibetan phonology, it is preferable to see $l h$ as a voiceless lateral $/ 1 /$ and regard its aspiration as moot.

The same argument can be repeated for $h r$, but here preaspiration is not only not phonemic but otherwise unknown in Old Tibetan, although it does occur in some dialects (J. Sun 1986: 17). The difference between $r$ and $h r$ on the one hand and $l$ and $l h$ on the other occurs only in prevowel position, which is exactly where a contrast in voicing is shown. This fact further supports the analysis of this distinction as one of voicing.

Morphological considerations also favor the analysis of $<\mathrm{lh}>$ and $<\mathrm{hr}>$ as the voiceless correspondents of $<1>$ and $<\mathrm{h}\rangle$. The letter $<\mathrm{k}>$ occurs as the initial of a complex onset only before an $<1>$. Voicing is not distinctive at this position, and in general only voiced letters are written in this position. That this $k$ can be identified as an allomorph of the usual $g$ in the same position is shown by the use of $k$ - as a present stem prefix exactly parallel to a $g$ - present stem prefix before other consonants. Like the $g$ - present stem prefix, the $k$ - present stem prefix is accompanied by an $a$ to $o$ ablaut in the stem, e.g. klog, blags, (klag), lhogs 'read' in contrast to, for example, gsod, bsad, gsad, sod 'kill'. In such a case, the $<\mathrm{k}>$ rather than the $<1>$ indicates the voicelessness of the cluster, and thereby distinguishes $/ \mathrm{gl} / \mathrm{from}$ $<\mathrm{kl}>/ \mathrm{gl} / \mathrm{kl}$ ]. Writing $<\mathrm{glh}>$ for $[\mathrm{kl}]$ instead of $<\mathrm{kl}>$ would have been another possibility, but it was not favoured. ${ }^{9}$

Based on the stem forms, the root of this verb is clearly /lag/, and one would therefore expect that the initial cluster of the past stem would also be voiceless. Unfortunately the standard orthography of both Old Tibetan and Written Tibetan provides no means to distinguish /bl/ and /bl/. However, de Jong (1973: 310-11) collects the variant past-stem forms plags, phlags, and plhags which do clearly indicate that the entire cluster was voiceless. Old Tibetan had two laterals, $<1>/ 1$ and $<1 \mathrm{~h}>/ 1$.

Just as the morpheme $g$ - has the variant $k$ - before laterals, so too the morpheme $s$ - has the variant $z$ - before laterals. Hahn has assembled the following examples where $z$ - occurs before the voiced laterals, and where $s$ - occurs before the voiceless:

lo 'Bericht [a report]', zlo-ba 'berichten, sagen [to say, report]'

log-pa 'umgekehrt [backward]', zlog-pa 'umkehren lassen [to make turn around]'

lhes-ma 'Flechte [a braid]', sle-ba 'flechten [to braid]' (Hahn [1999]2003: 145)

\footnotetext{
${ }^{9}$ This analysis was first fully proposed by de Jong (1973); however, a year earlier Sprigg mentions Pullyblank making a similar proposal to him privately (Sprigg 1972: 552 n. 10). Much earlier Li had implied such an analysis (1933: 139-40).
} 
Since voiced lateral initials are much more common than voiceless lateral initials, while the written cluster $\langle\mathrm{zl}\rangle$ is much rarer that $\langle\mathrm{sl}\rangle$, there is reason to believe that the spelling $<\mathrm{sl}>$ can be used both for $/ \mathrm{sl} /$ and $/ \mathrm{sl} /$, while $<\mathrm{zl}>$ specifies $/ \mathrm{sl} /$ only. ${ }^{10}$

The morphological evidence for $<\mathrm{hr}>/ \mathrm{r} /$ is not as copious, in large part because there appear to be no verb roots with initial $<\mathrm{hr}>/ \mathrm{r} /$. Hahn offers as evidence:

hrum-pa 'zerbrechen [to break]' and krum-pa 'angebrochen [fractured]' ([1999]2003: 145).

The voiceless $/ \mathrm{l} /$ is written $<\mathrm{lh}>$ with the $<\mathrm{h}>$ after the $<1>$, whereas the voiceless $<\mathrm{r}>$ is written $<\mathrm{hr}\rangle$ with the $\langle\mathrm{h}\rangle$ before the $\langle\mathrm{r}\rangle$. I am not able to offer an explanation for this asymmetry. The failure of the Tibetan script to give these sounds their own letters may perhaps be ascribed to their absence in Indic scripts.

\subsection{Uvulars}

J. Sun (2003: 783), following Huang (1991: 230-35), has suggested that the presence of uvulars in some Tibetan languages can be taken as evidence for reconstructing uvular consonants in Common Tibetan. Sun does not say whether he believes Old Tibetan had uvulars. If Old Tibetan did not have uvulars, one may object that he makes no attempt to explain how uvulars could have emerged between Old Tibetan and Common Tibetan. If Old Tibetan did have uvulars, one can object that he makes no attempt to explain why they were not orthographically distinguished from the velars. All of the Tibetan languages which have uvular reflexes are in Eastern Tibet, where other languages have also developed uvular consonants, e.g. the Mongolian languages Monguor or Bonan (Svantesson, Tsendina, Karlsson \& Franzén 2005: 151-2). The region can be regarded as a uvular-prone Sprachbund. Most or all of the modern Qiangic languages, which appear to be native to the region, have uvulars. In the Rgyalron sub-branch of Qiangic, uvulars can be reconstructed to the Proto-Rgyalron level (Jacques 2004: 305-10). Although no reconstruction of protoQiangic is yet available, it is not unlikely that uvulars may be reconstructed for protoQiangic also. It seems uvulars have an older pedigree in the Qiangic language family than in Mongolian or Tibetan. The emergence of uvulars in Tibetan and Mongolian languages in this region is likely due to the influence of a Qiangic substrate. Before 1950 most Rgyalron speakers were bilingual in Amdo Tibetan and Rgyalron. Although knowledge of Mongolian among Qiangic speakers is not well attested, many Mongolian speakers in the region are bilingual with Tibetan; perhaps these varieties of Mongolian developed uvulars under the influence of Tibetan languages which had already developed them through a Qiangic substrate. Until further investigation reveals uvulars in the same sets of words across Tibetan languages which cannot be related except at the level of Common Tibetan, it is more judicious to leave Common Tibetan, and its immediate ancestor Old Tibetan, free of uvulars.

\footnotetext{
${ }^{10}$ Hahn further suggests that the two clusters $<\mathrm{lt}>$ and $<\mathrm{ld}>$ are metathesised forms of *tl and *dl, which like in the case of $<\mathrm{kl}>$ and $<\mathrm{gl}>$ indicate $* / \mathrm{dl} /$ and $* / \mathrm{dl} /$ respectively. He cites the following examples in support of this

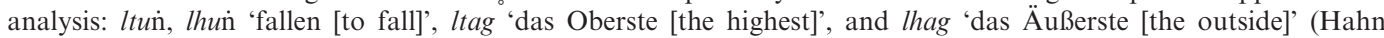
[1999]2003: 146). He also suggests that a similar metathesis occurred in the word lpags 'Haut [skin]' $(<*$ plags $=$ blags), comparing it with lhag 'das Äuser(st)e [the outer (most)]' (Hahn [1999]2003: 146). Since < blags > can already represent /blags/ as shown above, I believe the etymology of lpags should be sought elsewhere.
} 


\section{Phonotactics ${ }^{11}$}

The Old Tibetan syllable has the structure $\mathrm{C}_{1} \mathrm{C}_{2} \mathrm{C}_{3} \mathrm{G}_{1} \mathrm{G}_{2} \mathrm{VC}_{4} \mathrm{C}_{5}$. All positions except for $\mathrm{C}_{3}$ and $\mathrm{V}$ are optional. Analysing the onset of syllables beginning with one or two consonants as $\mathrm{C}_{3}$ and $\mathrm{C}_{2} \mathrm{C}_{3}$ and rather than $\mathrm{C}_{1}$ and $\mathrm{C}_{1} \mathrm{C}_{2}$ greatly simplifies the statement of phonotactic possibilities. Words of the structure $q \mathrm{~V}$ could be analysed as $\mathrm{C}_{3} \mathrm{~V}$ or just $\mathrm{V}$, depending on whether one sees $q$ as representing the absence of a consonant or the presence of a glottal stop. However, since so far no genuine Old Tibetan words have come to light which begin with $q$-, the question is moot.

Only the phoneme $/ \mathrm{b} /$ can stand in position $\mathrm{C}_{1}{ }^{12}$ The consonants which may stand in position $\mathrm{C}_{2}$ are $/ \mathrm{d}-/$, g-/ (written as $k$ before $/ 1 /$, vide supra), $/ \mathrm{b}-/, / \mathrm{m}-/, / \mathrm{s}-/, / \mathrm{r}-/$, and $/ 1-/{ }^{13}$ In position $\mathrm{C}_{2}$ the phonemes $/ \mathrm{d}-/$ and $/ \mathrm{g}-/$ are in complementary distribution, and may be treated as members of the same archiphoneme. The form $/ \mathrm{d}-/$ occurs before the grave consonants $/ \mathrm{k} /, / \mathrm{g} /, / \dot{\mathrm{n}} /, / \mathrm{p} /, / \mathrm{b} /$, and $/ \mathrm{m} /$, and $/ \mathrm{g}-/$ occurs before the acute consonants $/ \mathrm{t} /$, $/ \mathrm{ts} /, / \mathrm{d} / / \mathrm{n} /, / \mathrm{s} / / \mathrm{z} /, / \mathrm{l} /$, and $/ \mathrm{l} /$ (cf. Li 1933: 136, 146-7, Beyer 1992: 88). ${ }^{14}$ Neither $/ \mathrm{d}-/$ nor $/ \mathrm{g} / /$ occurs before $/ \mathrm{dz} /$. The clusters $/ \mathrm{dr} /$ and $/ \mathrm{gr} / \mathrm{do}$ occur, but in these cases $/ \mathrm{d} / \mathrm{and} / \mathrm{g} /$ are in position $\mathrm{C}_{3}$ and $/ \mathrm{r} /$ in position $\mathrm{G}_{1} \cdot{ }^{15}$ The cluster $<\mathrm{kr}>$ could be analysed as $/ \mathrm{gr} /$, but since clusters such as $/ \mathrm{bkr} /$ also occur, ${ }^{16}$ it is better to analyse $<\mathrm{kr}>\operatorname{simply}$ as $/ \mathrm{kr} /$.

The entire spectrum of consonant phonemes may stand in position $\mathrm{C}_{3} .{ }^{17}$ The glides possible in position $\mathrm{G}_{1}$ are $\left\langle\mathrm{y}>/ \mathrm{i} /\right.$ and $/ \mathrm{r} /{ }^{18}$ Only $/ \mathrm{w} /$ occurs as $\mathrm{G}_{2}$. It is necessary to distinguish $\mathrm{G}_{1}$ from $\mathrm{G}_{2}$ to account for words such as phywa /piwa/ 'a class of indigenous deities' (Rkon-po inscription line 3, Li \& Coblin 1987: 198) and grwa /grwa/ 'corner' (PT 1134 lines 147 and 190). The number of such words increases when the palatalised consonants are regarded as palatalised dentals (e.g. < źwa > /zína/ 'hat' [PT 1283 line 1], < śwa > /sina/ 'deer' [ITJ 0738 folio 3 recto, line 67]). In position $\mathrm{C}_{4}$ are allowed $/ \mathrm{g} /, / \mathrm{d} /, / \mathrm{b} /, / \dot{\mathrm{n}} /, / \mathrm{n} /, / \mathrm{m} /, / \mathrm{s} /, / \mathrm{h} /, / \mathrm{r} /$ and $/ 1 /{ }^{19}$ In position $\mathrm{C}_{5}$ only $/ \mathrm{s} /$ and $/ \mathrm{d} /$ occur. They are in complementary distribution, with $/-\mathrm{s} /$ after graves $/ \mathrm{gs} /, / \mathrm{hs} /, / \mathrm{bs} /, / \mathrm{ms} /$, and $/ \mathrm{d} /$ after acutes $/ \mathrm{rd} /, / \mathrm{ld} /$, and $/ \mathrm{nd} / .^{20}$

\footnotetext{
${ }^{11}$ This section abbreviates 'consonant' as $\mathrm{C}$, 'glide' as $\mathrm{G}$, and 'vowel' as $\mathrm{V}$, as is conventional in the literature on phonotactics.

${ }^{12}$ Examples include bsgre 'age' (PT 1287 line 208) and brtsis 'count' (PT 0126 line 155).

${ }^{13}$ Examples include dkar-mo 'white female sheep' (PT 1042 line 132), gtam 'report' (PT 0739 folio 7 recto, line 7), klog /glog/ 'read' (PT 0441, cf. Bischoff 1956: 31 line 8), bcug 'insert' (ITJ 0750 line 160), minah 'own' (PT 1047 line 63), sku 'body' (PT 0016 folio 23 recto, line 3), rtul 'weak' (ITJ 0731 folio 3 recto, line 99), lina 'five' (PT 0999 line 4).

${ }^{14}$ Examples include dkar-mo 'white female sheep' (PT 1042 line 132), dgra 'enemy' (PT 0239 recto, line 06-2), dinul 'silver' (PT 1071 recto, line 16), dpal 'glory' (PT 1043 line 72), dban்-po 'power' (ITJ 0751 folio 35 recto, line 1), dmag 'war' (PT 1283 line 583), gtam 'report' (PT 0739 folio 7 recto, line 7), gtsigs 'edict' (PT 0016 folio 33 recto, line 1), gdon 'face' (PT 1038 line 9), gnam 'sky' (PT 1039 line 35), gsod 'kill' (PT 1283 line 237), gzugs 'form' (PT 0016 folio 24 recto, line 4), glo-ba 'mind, loyalty' (PT 1287 line 90), klog /glog/ 'read' (PT 0441, cf. Bischoff 1956: 31 line 8).

${ }^{15}$ Examples include dril-bu 'bell' (PT 1134 line 49) and gri 'knife' (PT 1084 line 2)

${ }^{16}$ For example, bkres 'hunger' (PT 0239 folio 2 recto, line 5).

${ }^{17}$ Examples include dkar-mo 'white female sheep' (PT 1042 line 132), dgra 'enemy' (PT 0239 recto, line 06-2), dinul 'silver' (PT 1071 recto, line 16), gtam 'report' (PT 0739 folio 7 recto, line 7), gdon 'face' (PT 1038 line 9), gnam 'sky' (PT 1039 line 35), dpal 'glory' (PT 1043 line 72), dban்-po 'power' (ITJ 0751 folio 35 recto, line 1), dmag 'war' (PT 1283 line 583), gtsigs 'edict' (PT 0016 folio 33 recto, line 1), hdzind 'take' (PT 1047 line 132), gzugs 'form' (PT 0016 folio 24 recto, line 4), hon 'come' (PT 1046B line 16), yod 'exist' (PT 1194 line 26), rins 'be long' (PT 0125 line 153), glo-ba 'mind, loyalty' (PT 1287 line 90), klog /glog/ 'read' (PT 044, cf. Bischoff 1956: 31 lines 8), gsod 'kill' (PT 1283 line 237), ha-chaì, a term used in divination (PT 1047 line 1). I have not found a clear example of / r $/$.

${ }^{18}$ Examples include sbyin 'give' (PT 1283 line 510), phyag /piag/ 'hand' (PT 1042 line 3), bsgre 'age' (PT 1287 line 208).

${ }^{19}$ Examples include $d m a g$ 'war' (PT 1283 line 583), gsod 'kill' (PT 1283 line 237), bab 'fall' (PT 1042 line 86), gźan 'other' (PT 1051 line 44), gsun ‘say' (PT 1134 line 214), gnam ‘sky' (PT 1039 line 35), minah ‘own' (PT 1047 line 63$)$, dkar-mo 'white female sheep' (PT 1042 line 132), dril-bu 'bell' (PT 1134 line 49), byas 'do' (PT 0126 line 39 ).

${ }^{20}$ Examples include gzugs 'form' (PT 0016 folio 24 recto, line 4), mdahs 'low' (ITJ 0734 folio 5 recto, line 182), chibs 'horse' (PT 1042 line 133), sems 'mind' (PT 1283 line 37), gyurd 'become' (ITJ 0734 folio 1 recto, line 10), stsald 'give' (PT 1071 recto, line 46), hdzind 'take' (PT 1047 line 132).
} 
There is a voicing contrast only at position $\mathrm{C}_{3}$. The voicing of consonants in positions $\mathrm{C}_{1}$ and $C_{2}$ agrees with that of the consonant at position $C_{3}$ (cf. Sprigg 1974: 261). This can be

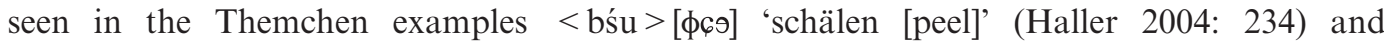
$<$ bźu $>$ [bzo] 'schmelzen [melt]' (Haller 2004: 221). Róna-Tas discusses in some detail the assimilation of $s$ - to the voicing of its following consonant in the modern Tibetan languages (1966: 141).

All finals are pronounced as voiceless, despite being written as voiced (Sprigg 2002: 11; Haller 2004: 25), for example, the words <gtub > /gtup/ 'cut to pieces, mince' and $<$ dmag > /rmak/ 'army' in Balti (Sprigg 2002: 71, 191) and < gtub > /çtəp / 'schneiden, würfeln [slice, dice]' and < dmag $>/$ yma / 'soldat [soldier]' in Themchen (Haller 2004: 227, 242). One can point to words such as words as $<$ tha ga pa $>$ 'weaver' and $<$ bu ga $>$ 'hole' from $<$ ḥthag $>$ 'weave' and $<$ ḥbug $>$ 'pierce', respectively, as evidence that these final consonants voice when between two vowels. In the words $<$ tha ga pa $>$ 'weaver' and $<$ bu ga $>$ 'hole' these consonants appear in $\mathrm{C}_{3}$ position, where voiceless consonants are also permitted. Therefore it is more judicious to regard these consonants as underlyingly voiced and as losing their voicing before silence, just as is done with German or Russian. Similar analysis leads J. Sun (1986: 35-6) to regard the finals in the Mdzo-dge-sde-pa Tibetan language of Amdo as underlyingly voiced.

\section{Summary: the consonant phonemes of Old Tibetan}

The Tibetan script distinguishes the following letters, and a first approximation of Old Tibetan phonology would take each as a phoneme.

k, kh, g, n, c, ch, j, n, t, th, d, n, p, ph, b, m, ts, tsh, dz, w, ź, z, ha, y, r, l, ś, s, h

When one realises that aspiration is not a phonemic contrast, this list is significantly reduced.

$\mathrm{k}, \mathrm{g}, \dot{\mathrm{n}}, \mathrm{c}, \mathrm{j}, \tilde{\mathrm{n}}, \mathrm{t}, \mathrm{d}, \mathrm{n}, \mathrm{p}, \mathrm{b}, \mathrm{m}, \mathrm{ts}, \mathrm{dz}, \mathrm{w}, \mathrm{z}, \mathrm{z}, \mathrm{h}, \mathrm{y}, \mathrm{r}, \mathrm{l}, \dot{s}, \mathrm{~s}, \mathrm{~h}$

Parallel to the distinction between $/ \mathrm{b} /$ and $/ \mathrm{w} /$, a distinction must be drawn between $/ \mathrm{y} /$ and a phonemic feature of palatalisation $/ \mathrm{i} /$. This adds an additional phoneme to the list.

$\mathrm{k}, \mathrm{g}, \dot{\mathrm{n}}, \mathrm{c}, \mathrm{j}, \tilde{\mathrm{n}}, \mathrm{t}, \mathrm{d}, \mathrm{n}, \mathrm{p}, \mathrm{b}, \mathrm{m}, \mathrm{ts}, \mathrm{dz}, \mathrm{w}, \mathrm{z}, \mathrm{z}, \mathrm{h}, \mathrm{y}, \mathrm{r}, \mathrm{l}, \dot{s}, \mathrm{~s}, \mathrm{~h}, \mathrm{i}$

An additional reduction can be made by analysing the palatals as palatalised dentals.

$\mathrm{k}, \mathrm{g}, \dot{\mathrm{n}}, \mathrm{t}, \mathrm{d}, \mathrm{n}, \mathrm{p}, \mathrm{b}, \mathrm{m}, \mathrm{ts}, \mathrm{dz}, \mathrm{w}, \mathrm{z}, \mathrm{h}, \mathrm{y}, \mathrm{r}, \mathrm{l}, \mathrm{s}, \mathrm{h}, \mathrm{i}$

The contrast of voicing extends to $/ \mathrm{r} /$ and $/ \mathrm{l}$, so two more phonemes must be added.

$\mathrm{k}, \mathrm{g}, \dot{\mathrm{n}}, \mathrm{t}, \mathrm{d}, \mathrm{n}, \mathrm{s}, \mathrm{z}, \mathrm{p}, \mathrm{b}, \mathrm{m}, \mathrm{ts}, \mathrm{dz}, \mathrm{y}, \mathrm{r}, \mathrm{r}, \mathrm{l}, \mathrm{l}, \mathrm{h}, \mathrm{h}, \mathrm{w}, \mathrm{i}$

This final list gives a complete account of the phonemes of Old Tibetan. A more thorough analysis of Old Tibetan phonology, in terms of supersegmental features and the domains to which they attach, may be able to give an even more elegant and accurate description of the Old Tibetan phonemic and phonotactic systems. Such an analysis would consider, for example, that voicing can only occur once in a word, while palatalisation can occur once in a syllable. The prohibition against syllable onsets of the type /*bsb-/ could also be analysed in terms of features.

Department of China and Inner Asia

School of Oriental and African Studies, University of London

Thornhaugh Street, Russell Square, London WC1H OXG, UK

Email:nh36@soas.ac.uk 


\section{REFERENCES}

Beckwith, Christopher I., 2006. 'The Sonority Sequencing Principle and Old Tibetan syllable margins', in Christopher I. Beckwith (ed.), Medieval Tibeto-Burman Languages II, Leiden: Brill, 45-57.

Beckwith, Christopher \& Walter, Michael, 1997. 'Some Indo-European elements in early Tibetan culture', in Ernst Steinkellner (ed.), Tibetan Studies: Proceedings of the 7th Seminar of the International Association for Tibetan Studies, Graz 1995, Vienna: Östereichische Akademie der Wissenschaften, 1037-55.

Benedict, Paul K., 1972. Sino-Tibetan: A Conspectus, Cambridge: Cambridge University Press.

Beyer, Stephen, 1992. The Classical Tibetan Language, Albany: State University of New York Press. Reprinted 1993 Delhi: Sri Satguru.

Bielmeier, Roland, 1985. Das Märchen von Prinzen Čobzan, Sankt Augustin: WGH Wissenschaftsverlag.

Bielmeier, Roland, 2004. 'Shafer's proto-West Bodish hypothesis and the formation of the Tibetan verb paradigms', in Anju Saxena (ed.), Himalayan Languages Past and Present, Berlin: Mouton de Gruyter, 395-412.

Bischoff, F. A., 1956. Contribution à l'étude des divinités mineures du Bouddhisme tantrique; Ārya mahābala-nāmamahāyānasutra, tibétain (mss. de Touen-houang) et chinois. Paris: P. Geuthner.

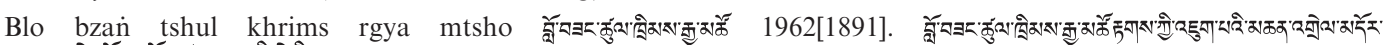

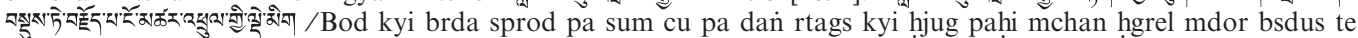
brjod pa ngo mtshar hphrul gyi lde mig [Tibetan grammar: collected notes on the Sum cu pa and Rtags kyi vjug pa,

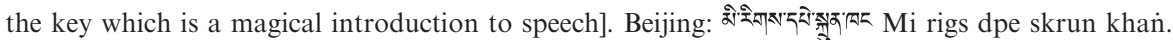

CHE QIAN 車謙 1981. “從 gcig 談起一關於古藏語聲母中清塞音、塞擦音送氣和不送氣問題 Cong gcig tanqi: guanyu gu Zangyu shengmu zhong qingseyin secayin songqi he bu songqi wenti' [Starting from gcig: concerning the aspiration of initials of voiceless plosives in Ancient Tibetan], 民族語文 Minzu Yuwen 2: 36-9.

CHE QIAN 車謙 1984. ‘古藏語裏有复合元音嗎 Gu Zangyu li you fuhe yuanyin ma?' [Did Old Tibetan have diphthongs?], 中央民族學院學報 Zhongyang Minzu Xueyuan Xuebao 3: 102-5.

CHE QIAN 車謙, 1991. 'On certain Tibetan and Chinese phonological questions of the medieval period', Linguistics of the Tibeto-Burman Area 14: 65-92.

Denwood, Philip, 1999. Tibetan, Amsterdam: Benjamins.

Dotson, Brandon, 2009. The Old Tibetan Annals: An Annotated Translation of Tibet's First History, Vienna: Verlag der österreichischen Akademie der Wissenschaften.

Dragunov, A., 1936. 'Voiced plosives and affricates in ancient Tibetan', Bulletin of the Institute of History and Philology, Academia Sinica 7, 165-74.

Dragunov, Aleksandr A. Драгунов, Александр А. (1939). “Особенности фонологическои системы древнетибетского языка / Osobennosti fonologičeskoi sistemy drevnetibetskogo jazyka." [Peculiarities of the Old Tibetan Phonological System.] Эаписки института востоковеденииа Акад. Наук ССР / Zapiski Instituta vostokovedeniia Akad. Nauk SSR 7: 284-295.

van Driem, George, 2001. Languages of the Himalayas, Leiden: Brill.

van Driem, George, 2003. 'Tibeto-Burman vs. Sino-Tibetan', in Brigitte Bauer \& Georges-Jean Pinault (eds.), Language in Time and Space: A Festschrift for Werner Winter on the Occasion of his 80th Birthday, Berlin: Mouton de Gruyter, 101-19.

Emmerick, R. E., 1983. 'Some more loanwords in Khotanese', Die Sprache 29.1: 43-9.

Emmerick, R. E., 1985. 'Tibetan loanwords in Khotanese and Khotanese loanwords in Tibetan.', in Orientalia Iosephi Tucci Memoriae Dicata, Rome: Istituto italiano per il medio ed estremo oriente, 301-19.

Hahn, Michael, 1973. 'Grundfragen der tibetischen Morphologie', Zentralasiatiche Studien 7, 425-42.

Hahn, Michael, 1994. Lehrbuch der klassischen tibetischen Schriftsprache, Swisttal-Odendorf: Indica et Tibetica Verlag.

Hahn, Michael, 1999. 'Blags und Verwandtes (Miscellanea Etymologica tibetica VII)', in Helmut Eimer, Michael Hahn et al. (eds.), Studia Tibetica et Mongolica: Festschrift für Manfred Taube, Swisttal-Odendorf: Indica et Tibetica Verlag, 123-6. Reprinted in Hahn (2003: 144-6).

Hahn, Michael, 2003. Schlüssel zum Lehrbuch der klassischen tibetischen Schriftsprache und Beiträge zur tibetischen Wortkunde (Miscellanea etymologica tibetica I-VI), Marburg: Indica et Tibetica Verlag.

Haller, Felix, 2000. Dialekt und Erzählungen von Shigatse, Bonn: VGH Wissenschaftsverlag.

Haller, Felix, 2004. Dialekt und Erzählungen von Themchen: sprachwissenschaftliche Beschreibung eines Nomadendialektes aus Nord-Amdo, Bonn: VGH Wissenschaftsverlag.

Herrmann, Silke, 1989. Erzählungen und Dialekt von Dinri, Bonn: VGH Wissenschaftsverlag

Hill, Nathan, 2005. 'Once more on the letter २', Linguistics of the Tibeto-Burman Area 28.2: 111-41.

Hill, Nathan, 2006. 'Tibetan $v w a$ 'fox' and the sound change Tibeto-Burman *wa $\rightarrow$ Old Tibetan o', Linguistics of the Tibeto-Burman Area 29.2: 75-90.

Hill, NAthan, 2007. ‘Aspirate and non-aspirate voiceless consonants in Old Tibetan', 語言暨語言學 Languages and Linguistics 8.2: 471-93.

Hill, Nathan, 2009a. 'The Hphags-pa letter г and laryngeal phenomena in Mongolian and Chinese', Central Asiatic Journal 53.2: 183-205.

Hill, Nathan, 2009b. 'Tibetan $<\mathrm{h}>-$ as a plain initial and its place in Old Tibetan phonology', Linguistics of the Tibeto-Burman Area 32.1: 115-40

Hill, Nathan (forthcoming). 'The difference between Tibetan $<$ gy $>$ and $<$ g.y $>$ ', in Nathan Hill (ed.), Medieval Tibeto-Burman Languages IV, Leiden: Brill.

Hodge, Stephen, 1990. An Introduction to Classical Tibetan, Warminster: Aris \& Phillips. 
HuAng, Bufan 美語支, 1991. ‘漢藏語概論 Qiangyuzhi’ [Qiangic branch], in Ma Xueliang et al. (eds.), 漢藏語概論 Hanzangyu Gailun [A General Introduction to Sino-Tibetan Languages], Beijing: Beijing University Press, $208-369$. Ivanov, V. V. (1961). “Тибетские кальки в тохарских текстах Tibetskie kal'ki v tocharskich tekstach [Tibetan calques in Tocharian texts].” Краткие сообщения института народов Азии / Kratkie soobshchenija instituta narodov Azii 57: 35-40.

Jacques, Guillaume, 2004. 'Phonologie et morphologie du Japhug (rGyalrong)', dissertation, Université Paris VII Denis Diderot.

Jäschke, Heinrich August, 1868. 'Ueber die Phonetik der tibetischen Sprache', Monatsberichte der königlichen preussischen Akademie des Wissenschaften zu Berlin, 148-82.

Jäschke, Heinrich August, 1881. Tibetan English Dictionary, London: Unger.

DE Jong, JAN Willem, 1973. 'Tibetan blag-pa and blags-pa', Bulletin of the School of Oriental and African Studies 36 : 209-12. Reprinted 1994 in Tibetan Studies, Swisttal-Odendorf: Indica et Tibetica Verlag: 182-6

Kretschmar, Monika, 1986. Erzählungen und Dialekt der Drokpas aus Südwest-Tibet, Sankt Augustin: VGH Wissenschaftsverlag.

Laufer, Berthold, 1898/99. 'Über das va zur. Ein Beitrag zur Phonetik der tibtischen Sprache', Wiener Zeitschrift für die Kunde des Morgenlandes 12: 289-307; 13: 95-109, 199-226. Reprinted 1976 in Kleinere Schriften von Berthold Laufer, ed. Hartmut Walravens, Wiesbaden: Steiner, 61-122.

Laufer, Berthold, 1914. 'Bird divination among the Tibetans: notes on document Pelliot no. 3530, with a study of Tibetan phonology of the ninth century', T'oung pao 15: 1-110. Reprinted 1987 in Hartmut Walravens \& Lokesh Candra (eds.), Sino-Tibetan Studies, vol. 2, New Delhi: Rakesh Goel, 354-463.

Laufer, Berthold, 1916/18. 'Loan words in Tibetan', T'oung Pao 17: 404-552. Reprinted 1987 in Hartmut Walravens \& Lokesh Candra (eds.), Sino-Tibetan Studies, vol. 2, New Delhi: Rakesh Goel, 483-632.

Laufer, Berthold, 1918. 'Origin of Tibetan writing', Journal of the American Oriental Society 38: $34-46$.

Laufer, Berthold, 1919. 'Additional notes on loan words in Tibetan', in Sino-Iranica: Chinese Contributions to the History of Civilization in Ancient Iran, Chicago: Field Museum of Natural History, 591-7.

LeE, Don, 1981. The History of Early Relations between China and Tibet. Bloomington, IN: Eastern Press.

Li FAnG-Kuei, 1933. 'Certain phonetic influences of the Tibetan prefixes upon the root initials', Bulletin of the Institute of History and Philology 6.2: 135-57.

Li Fang-Kuei \& Coblin, Weldon South, 1987. A Study of the Old Tibetan Inscriptions, Taipei: Academia Sinica.

Ligeti, Louis, 1961. 'Trois notes sur l'écriture "phags-pa", , Acta Orientalia Academiae Scientificarum Hungaricae 13: 201-37.

Lorimer, David L. R., 1938. The Burushaski Language, vol. 3: Vocabularies and Index, Oslo: Instituttet for sammenlignende kulturforskning.

Matisoff, James, 2003. Handbook of Proto-Tibeto-Burman, Berkeley: University of California Press.

Miller, Roy Andrew, 1955a. 'Studies in spoken Tibetan I: phonemics', Journal of the American Oriental Society 75 : 46-51.

Miller, Roy Andrew, 1955b. 'Notes on the Lhasa dialect of the early ninth century', Oriens 8: 284-91.

Miller, Roy Andrew, 1966. 'Early evidence for vowel harmony in Tibetan', Language 42: 252-77.

Miller, Roy Andrew, 1967. 'Some problems in Tibetan transcription of Chinese from Tun-huang', Monumenta Serica 27: 123-48 (publ. 1969).

Miller, Roy Andrew, 1993. Prologomena to the First Two Tibetan Grammatical Treatises, Vienna: Arbeitskreis für Tibetische und Buddhistische Studien Universität Wien.

Pelliot, Paul, 1961. Histoire Ancienne du Tibet, Paris: Adrien-Maisonneuve.

Petech, Luciano, 1977. The Kingdom of Ladakh c. 950-1842 A.D., Rome: Istituto italiano per il medio ed estremo oriente.

Richardson, Hugh E., 1985. A Corpus of Early Tibetan Inscriptions, London: Royal Asiatic Society.

de Roerich, George, 1957. 'Tibetan loan-words in Mongolian', in Kshitis Roy (ed.), Festschrift Liebenthal, Santiniketan: Visvabharati, 174-80.

RónA-Tas, Andras, 1962. 'Tibetan loan-words in the Shera Yögur Language', Acta Orientalia Scientificarum Hungaricae 15: 259-71.

Róna-Tas, Andras, 1966. Tibeto-Mongolica: The Loanwords of Mongour and the Development of the Archaic Tibetan Dialects, The Hague: Mouton.

RónA-Tas, Andras, 1985. Wiener Vorlesungen zur Sprach- und Kulturgeschichte Tibets, Vienna: Arbeitskreis für Tibetische und Buddhistische Studien.

RónA-TAS, Andras, 1992. 'Reconstructing Old Tibetan', in Ihara Shoren \& Yamaguchi Zuiho (eds.), Tibetan Studies: Proceedings of the 5th Seminar of the International Association for Tibetan Studies, Narita 1989, vol. 2, Narita: Naritasan Shinshoji, 697-704.

SAPIR, EdWARD, 1936. 'Tibetan influences on Tocharian, I', Language 12: 259-71. Reprinted 1949 in Selected Writings of Edward Sapir in Language, Culture, and Personality, ed. David G. Mandelbaum, Berkeley: University of California Press, 273-84.

VAN SCHAIK, SAM, 2007. 'Oral teachings and written texts: transmission and transformation in Dunhuang', in Matthew Kapstein \& Brandon Dotson (eds.), Contributions to the Cultural History of Early Tibet, Leiden: Brill, $183-210$.

Shafer, Robert, 1966. An Introduction to Sino-Tibetan: Part 1, Wiesbaden: Harrassowitz.

Sprigg, Richard Keith, 1967. Review of Róna-Tas 1966, Bulletin of the School of Oriental and African Studies 30.1: 216-17. 
Sprigg, Richard KeIth, 1972. 'A polysystemic approach, in Proto-Tibetan reconstruction, to tone and syllable-initial consonant clusters', Bulletin of the School of Oriental and African Studies 35.3: 546-87.

Sprigg, Richard Keith, 1974. Review of James A. Matisoff's 'The Loloish Tonal Split Revisited', Bulletin of the School of Oriental and African Studies 37.1: 259-62.

Sprigg, Richard Keith, 2002. Balti-English English-Balti Dictionary, Richmond, UK: Routledge Curzon.

Sun Hongkai, 2003. 'Is Baima a dialect or vernacular of Tibetan?', Cahiers de Linguistique - Asie Orientale 31.1: 6181.

Sun, Jackson T. S., 1986. Aspects of the Phonology of Amdo Tibetan: Ndzorge Śrme Xyra Dialect, Tokyo: Institute for Languages and Cultures of Asia and Africa.

Sun, JACKSON T. S., 2003. 'Phonological profile of Zhongu: a new Tibetan dialect of Northern Sichuan', Language \& Linguistics 4.4: 769-836.

Svantesson, Jan-Olof, Tsendina, Anna, Karlsson, Anastasia \& Franzén, Vivian, 2005. The Phonology of Mongolian, Oxford: Oxford University Press.

TAKATA, TOKIO 高田時雄, 1988. 敦煌資料による中国語史の研究 Tonkō shiryō ni yoru Chūgokugo shi no kenkyū [A study of the history of the Chinese language based on Dunhuang materials], Tokyo: Sobusha.

Takeuchi, Tsuguhito, 1990. 'A group of Old Tibetan letters written under Kuei-i-chun: a preliminary study for the classification of Old Tibetan letters', Acta Orientalia Academiae Scientiarum Hungaricae 44.1/2: 175-90.

Tournadre, Nicolas \& Dorje, Sangda, 2003. Manual of Standard Tibetan, trans. Charles Ramble, Ithaca, NY: Snow Lion Publications.

Ulving, Tor, 1972. 'Tibetan vowel harmony reexamined', T'oung Pao 58: 203-17.

Uray, GÉzA, 1955. 'On the Tibetan letters ba and wa: contribution to the origin and history of the Tibetan alphabet', Acta Orientalia Academiae Scientiarum Hungaricae 5.1: 101-21.

Uray, GÉzA, 1981. 'L’emploi du tibétain dans les chancelleries des états du Kan-sou et de Khotan postérieurs à la domination tibétaine', Journal Asiatique 269.1/2: 81-90.

Uray, GÉZA, 1988. 'New contributions to Tibetan documents from the post-Tibetan Tun-huang', in Helga Uebach \& Jampa L. Panglung (eds.), Tibetan Studies: Proceedings of the 4th Seminar of the International Association for Tibetan Studies Schloss Hohenkammer, Munich 1985, Munich: Kommission für Zentralasiatische Studien Bayerische Akademie der Wissenschaften, 514-528.

Walleser, Max, 1926. Zur Aussprache des Sanscrit und Tibetischen, Heidelberg: Harrassowitz.

ZHANG JiCHUAN 張繼川,1996. ‘古代藏語方音差別與正字法 Gudai Zangyu fangyin chabie yu zhengzifa’ [Old Tibetan dialectal differences and Tibetan orthography], 民族語文/Minzu Yuwen 3: 22-4.

Zhang, JichuAN 張繼川, 1997. 'Particularité phonétique du Baima', Cahiers de Linguistique - Asie Orientale 26.1: 13153.

Zhang Lian Sheng, 1987. 'The consonant system of middle-old Tibetan and the tonogenesis of Tibetan', Ph.D. thesis, University of California, Berkeley. 